\title{
Awareness and wound assesment decrease surgical site infections
}

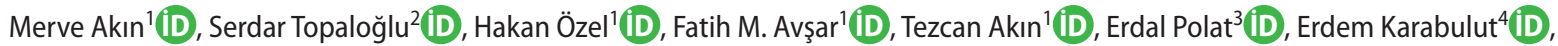
Süleyman Hengirmen ${ }^{5}$ (DD

${ }^{1}$ Clinic of General Surgery, Ankara City Hospital, Ankara, Turkey

2 Department of General Surgery, Karadeniz Technical University Faculty of Medicine, Trabzon, Turkey

${ }^{3}$ Clinic of Gastroenterological Surgery, Kartal Koşuyolu High Speciality Educational and Research Hospital, Istanbul, Turkey

${ }^{4}$ Department of Biostatics, Hacettepe University Faculty of Medicine, Ankara, Turkey

${ }^{5}$ Clinic of General Surgery, Ankara Numune Training and Research Hospital, Ankara, Turkey

\begin{abstract}
Objective: Various surveillance methods have been described for surveillance of surgical site infections (SSI). The aim of this study was to examine practicality of SSI risk assessment methods (SENIC and NNIS) with a postoperative wound monitoring scale (ASEPSIS) as an outcome assessment measure and evaluation of the contribution of wound assesment to the reduction of wound infection.

Material and Methods: Patients were followed with a prospective data chart through four year. Correlation of SENIC and NNIS together with ASEPSIS were performed.

Results: During the study period, 275 SSI occurred. SSIs were determined within the 21 days-period after operations. Correlation between SENIC with ASEPSIS ( $r s=0.41, p<0.001$ ) was found better than that for NNIS with ASEPSIS ( $r=0.37, p<0.001$ ). Type of operation (emergency vs. elective), body mass index, operation class and American Society of Anesthesiologists scores were found independently predictive factors for SSI. The forth year SSI rate was found to be significantly lower than the other years $(p<0.001)$.
\end{abstract}

Conclusion: This study indicates weak but significant correlation between preoperative risk assessment methods for SSI and ASEPSIS method. In addition, surgical wound assesment and awarness of the wound infection rates, have decreased the SSI rates over the years.

Keywords: Asepsis, senic, SSI, nnis

Cite this article as: Akın M, Topaloğlu S, Özel H, Avşar FM, Akın T, Polat E et al. Awareness and wound assesment decrease surgical site infections. Turk J Surg 2021; 37 (2): 133141.

\section{Corresponding Author}

Merve Akın

E-mail: merveakin.2002@gmail.com

Received: 21.09.2020

Accepted: 13.03 .202

Available Online Date: 30.06 .2021

o Copyright 2021 by Turkish Surgical Society Available online at www.turkjsurg.com

DOI: $10.47717 /$ turkjsurg.2021.5059

\section{INTRODUCTION}

Surgical site infection (SSI) continue to be the one of the most common nosocomial infection, accounting for more than $20 \%$ of all hospital-acquired infections (1). The incidence of SSI is $2 \%$ to $5 \%$ in patients undergoing surgery, which is the most common nosocomial infection in surgical patients, accounting for $38 \%$ of nosocomial infections in this patient population $(2,3)$. Surgical site infections are associated with increased length of stay results in an additional cost and a 2- to 11fold increase in the risk of mortality. Since SSIs can be preventable up to $60 \%$ by using evidence-based measures, accurate surveillance of wound complications has become a pay-for-performance metric and a target of quality-improvement efforts.

For this purpose, The Study on the Efficacy of Nosocomial Infection Control (SENIC) and the National Nosocomial Infections Surveillance (NNIS) system methods have been used predominantly for risk assessment of surgical wounds postoperative wound monitoring $(4,5)$. Since the most important step in surgical site infections is the recognition and definition of the infection; standardized, objective, traceable and easily applicable survaillance systems are required. It has been revealed that the scoring system with all these features is the "ASEPSIS" scoring defined by Wilson $(6,7)$. The main objective of this study was to examine corelation of NNIS and SENIC methods with ASEPSIS wound scoring method as an outcome assessment measure. In addition, factors affecting development of SSIs in different types of general surgical operations were investigated. 


\section{MATERIAL and METHODS}

A total of 2339 surgical procedures, excluding local and proctological procedures, were performed in our clinic (First Department of Surgery) in Ankara Numune Training and Research Hospital within four years. Prospective wound surveillance has been practiced for all patients having a surgical operation. The study protocol was approved by the local ethics committee.

A data chart including patient's risk index and postoperative wound monitoring is used to follow all surgical wounds. All charts are followed and completed by a senior resident and a senior staff surgeon in our department.

SENIC and NNIS indexes were used together for risk assessment of SSI. The SENIC risk index includes measurement of wound contamination and a proxy for the patient's susceptibility to infection. The NNIS risk index quantifies intrinsic and extrinsic measures of patient risk for developing an SSI. Both SENIC and NNIS indexes were eveluated according to the Table 1 and 2.

During wound surveillance, operations are classified into four categories according to their invasiveness. Surgical procedures in which the abdominal cavity is not entered (group 1); abdominal operations (excluding liver and major retroperitoneal operations) (group 2); thoracic operations (group 3); liver surgery and retroperitoneal operations (group 4) (9).
SSIs were evaluated according to the latest modifications of the Centers for Disease Control and Prevention (CDC) and ASEPSIS method $(6,7,10)$. The wound of each patient was evaluated daily by the surgeon and recorded. The wound was evaluated at 14. 17. and 21. days postoperatively in the absence of significant wound infection. Patients discharged without SSI, were checked by the resident surgeon in the postoperative first month and third month at the outpatient clinic.

Postoperative wound evaluation was made using the ASEPSIS method (Table 3). While scores between 0 and 5 were given for erythema and serous discharge in the wound; Scores between 0 and 10 were given for purulent discharge and wound dehiscence. Scoring was made according to the ratio of the present symptom to the wound area. This scoring was made for five days of the first seven days postoperatively. Extra points for five-day scoring in cases of antibiotic use (10 points), drainage with local anesthesia (5 points), debridement under general anesthesia (10 points), wound culture positiveness (10 points) and no wound healing in 14 days (5 points) was added $(6,7,11)$. The wounds are classified into five categories according to overall scores (Table 3 ). When the total score score was above 20, it was considered to have wound infection. Infected wounds were followed up until surgical infection regressed.

Table 1. SENIC SSI risk index

\begin{tabular}{|l|l|}
\hline Variable & SENIC risk index criteria for presence of a risk factor* \\
\hline Wound class, i.e., clean, clean-contaminated, Contaminated or dirty & $\begin{array}{l}\text { Contaminated or dirty infection. } \\
\text { If present, scores 1 point }\end{array}$ \\
\hline Type of operation & Abdominal operation. If present, scores 1 point \\
\hline Duration of operation & Operation lasting longer than 2 hours. If present, scores 1 point \\
\hline Discharge diagnosis & Patient having $\geq 3$ discharge diagnoses. If present, scores 1 point \\
\hline *Risk index is obtained by summing the scores of the individual variables. Ranges from 0 to 4. & \\
\hline
\end{tabular}

Table 2. NNIS SSI risk index

\begin{tabular}{|c|c|c|}
\hline Category & Variable & $\begin{array}{l}\text { NNIS risk index criteria for presence of a } \\
\text { risk factor* }\end{array}$ \\
\hline $\begin{array}{l}\text { Intrinsic degree of microbial contamination of } \\
\text { the surgical site }\end{array}$ & $\begin{array}{l}\text { Wound class, i.e. clean, clean-contaminated, } \\
\text { contaminated or dirty }\end{array}$ & $\begin{array}{l}\text { Contaminated or dirty infection. If present, } \\
\text { scores } 1 \text { point }\end{array}$ \\
\hline Duration of an operation & $\begin{array}{l}\text { Time, in hours, of the duration of the surgical } \\
\text { procedure from skin incision to skin closure }\end{array}$ & $\begin{array}{l}\text { Length of operation }>\text { T hours where } T \text { is the } \\
\text { approximate } 75 \text {. percentile of the duration of } \\
\text { the surgical procedure. } \\
T \text { is a surgical procedure-specific parameter. } \\
\text { If present, scores } 1 \text { point }\end{array}$ \\
\hline Makers for host susceptibility & $\begin{array}{c}\text { American Society of Anesthesiologists (ASA) } \\
\text { Physical Status Classification }\end{array}$ & $\begin{array}{l}\text { ASA score } 3,4 \text {, or } 5 \\
\text { If present, scores } 1 \text { point }\end{array}$ \\
\hline
\end{tabular}




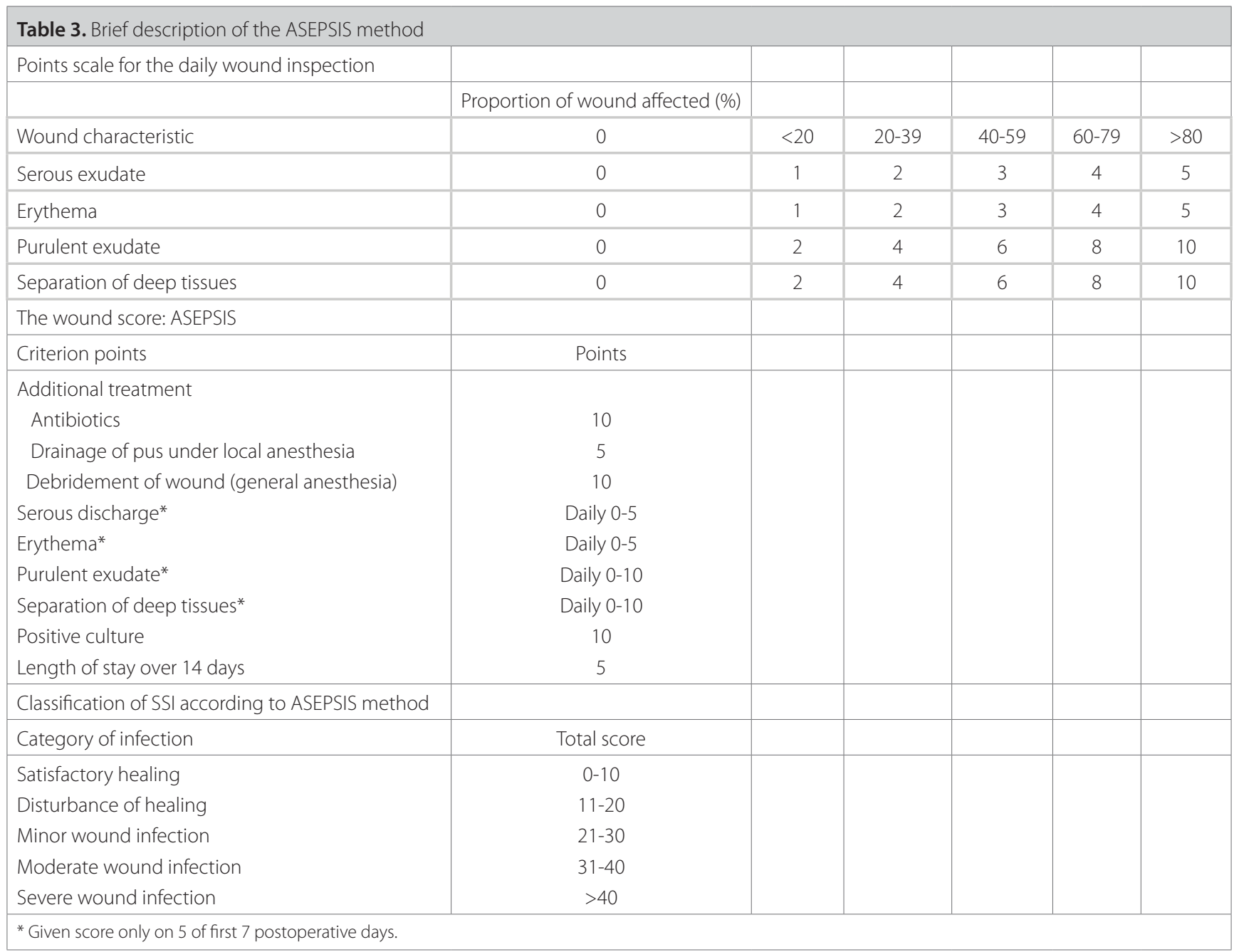

\section{Statistical Analysis}

Patients were divided into two groups as those with and without SSI, and bivariate analysis was performed, and all significance tests were performed with two-tailed. Comparative analysis of variables was done using the $x 2$ test. Correlation analysis between SENIC, NNIS, ASEPSIS methods was performed using Spearman correlation coefficient. The development of SSI was accepted as the dependent variable and multivariate analysis was performed by applying logistic regression using Wald statistics. In the multivariate analysis, those with a p value under 0.25 among the independent variables effective in the development of SSI, which were previously determined in the bivariate analysis, were used. All logistic regression results are given as odds ratio (OR) and with a $95 \%$ confidence interval $(\mathrm{Cl})$. All $p$ values were two-tailed and $p \leq 0.05$ values were considered significant.

\section{RESULTS}

During the study, a total of 2339 patients, 1108 (47.4\%) male and 1231 (52.7\%) female, were operated. The average age of the patients was 47.9 (range 6 to 95) years. All patients were followed for 21 days. This rate was 95\% at 30-day follow-up, and $86 \%$ at three-month follow-up. Average BMI was 25.9 (range 15.6 to 55.5). Of all operations, $88.4 \%$ were elective. During the study, 19 different operations were performed. Most operations were included in group $2(49 \%, n=1147)$ (Table 4).

Approximately $90 \%$ of the patients were scored as ASA II or ASA III. $84.7 \%$ of the operations were performed under general anesthesia. During the study, 275 SSIs were occured (11.8\% of 2339 operations). All SSIs developed within the postoperative 21-day period. SSI rates through years has shown at figure 1 and the decrease at forth year was statistically significant. While the SSI rate was $9.5 \%$ at elective operations, it was $28.3 \%$ for emergency operations $(p<0.001)$. SSI occurred in $1.7 \%$ in group 1 operations, $16.4 \%$ in group 2 operations, and $37.2 \%$ in group 4 operations ( $p<0.001$ among all groups). 134 of 275 patients had culture positive SSI (48.7\%). While this rate was $4.6 \%$ in elective operations, it was $13.6 \%$ in emergency operations. In general, a single microorganism isolated from the wound (75.1\%), and most of them were Escherichia coli (45.5\%) (Table 5). 
Table 4. Class of operation

\begin{tabular}{|c|c|c|}
\hline Operation & Group & $\mathrm{n},(\%)$ \\
\hline Thyroidectomy & Group 1 & $376(16.1)$ \\
\hline Pilonidal sinus surgery & Group 1 & $139(5.9)$ \\
\hline Modified radical mastectomy & Group 1 & $45(1.9)$ \\
\hline Inguinal hernia repair & Group 1 & $450(19.2)$ \\
\hline Inguinal hernia repair and Umbilical hernia repair & Group 2 & $6(0.3)$ \\
\hline Incisional hernia repair & Group 2 & $134(5.7)$ \\
\hline Incisional hernia repair and Cholecystectomy & Group 2 & $18(0.8)$ \\
\hline Umbilical hernia repair & Group 2 & $71(3)$ \\
\hline Umbilical hernia repair ve Cholecystectomy & Group 2 & $30(1.3)$ \\
\hline Appendectomy & Group 2 & $133(5.7)$ \\
\hline Gastrectomy and Repair of peptic ulcer perforation & Group 2 & $123(5.2)$ \\
\hline Splenectomy & Group 2 & $18(0.8)$ \\
\hline Colon resection and cholecystectomy (excluding retroperitoneal resection) & Group 2 & $20(0.1)$ \\
\hline Cholecystectomy & Group 2 & $579(24.8)$ \\
\hline Small intestine operations & Group 2 & $14(0.6)$ \\
\hline Liver hydatid cyst surgery & Group 4 & $68(2.9)$ \\
\hline Colon or rectum resection (including retroperitoneal resection) & Group 4 & $107(4.6)$ \\
\hline Pancreatectomy & Group 4 & $8(0.3)$ \\
\hline Liver hydatid cyst surgery and cholecystectomy & Group 4 & $9(0.4)$ \\
\hline
\end{tabular}

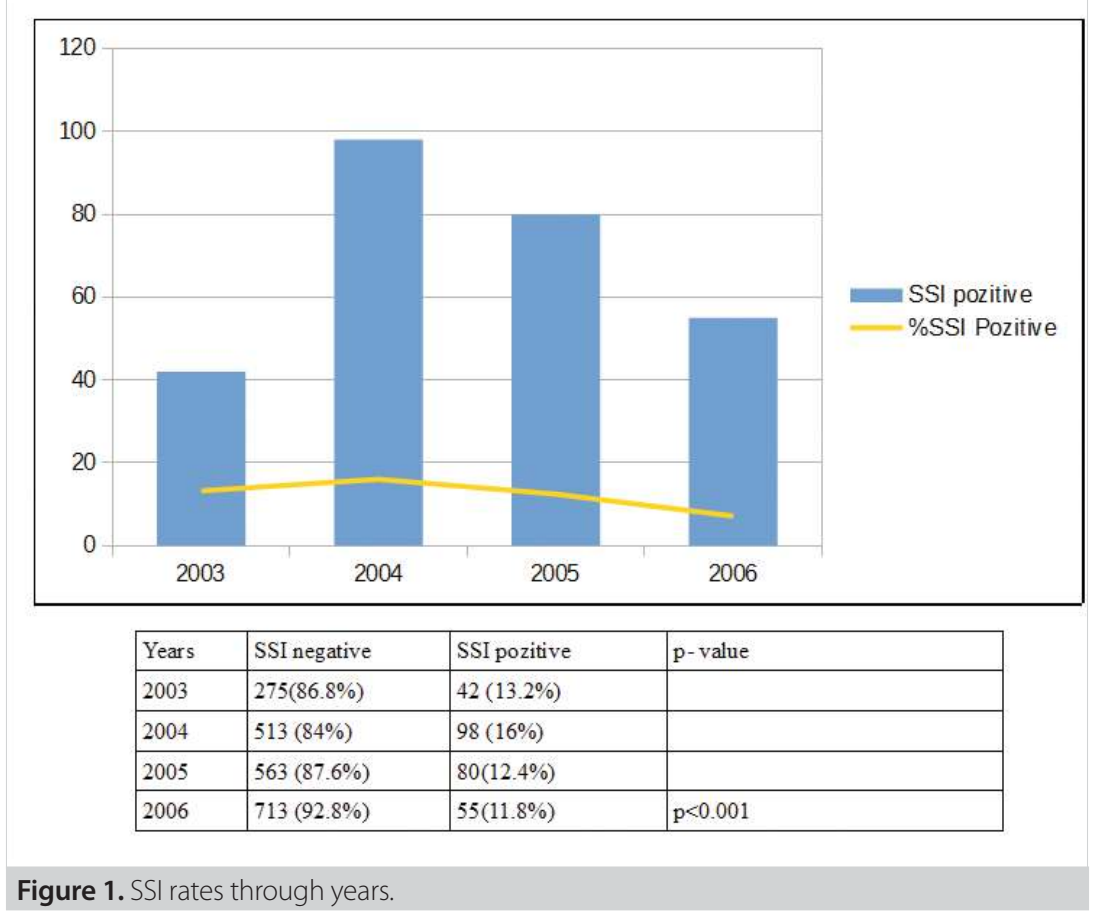

Patients were compared as with and without SSI. As BMI, age, and ASA scores increased, SSI rates also increased (Table 6). However, there was no difference in SSIs between men and women. Class of operation (group 1, 2 or 4), type of operation (elective or emergency), and type of anesthesia also affected the development of SSI. NNIS and SENIC risk indexes were as- signed in the preoperative period. Correlation between the SENIC risk index with the ASEPSIS ( $r s=0.41, p<0.001$ ) and a correlation between the NNIS risk index with the ASEPSIS ( $r s=0.37$, $\mathrm{p}<0.001$ ) were found to be statistically significant.

After bivariate analysis, BMI, age, ASA score, type and class of operation were selected as variables, since $p$ values were $<0.25$ 
Table 5. Microbial isolates from surgical wound infections

\begin{tabular}{|l|r}
\hline Species & Isolates (\%) \\
\hline Escherichia coli & $61(30.3)$ \\
MRSA* & $21(10.4)$ \\
Group D enterococcus & $21(10.4)$ \\
Pseudomonas aeruginosa & $19(9.4)$ \\
Bacteriodes fragilis & $17(8.4)$ \\
Klepsielle pneumonia & $17(8.4)$ \\
Coagulase-negative Staphylococcus & $14(6.9)$ \\
Fusobacterium species & $11(5.4)$ \\
a-Hemolytic streprococcus & $10(4.9)$ \\
Proteus miribalis & $9(4.4)$ \\
Acinetobacter species & $8(3.9)$ \\
Candida albicans & $1(0.4)$
\end{tabular}

* MRSA: Methicillin-resistant Staphylococcus aureus.

in the SSI development association, for logistic regression analysis. In this study, type of operation (emergency versus elective), BMI, operation class and ASA score were found to be independent variables in SSI development (Table 7).

\section{DISCUSSION}

Postoperative SSI is the most serious cause of morbidity and sometimes mortality. Comparison of the quality of surgical care provided among all health institutions is often made by considering the infection rates. Such comparisons are only valid if standard SSI definitions are made and permanent follow-up methods are used. Indexes indicating the risk of developing SSI, such as SENIC and NNIS, have been developed to compare patients' intrinsic and extrinsic risk factors between hospitals $(12,13)$. The SENIC risk index alone determines SSI risk better than wound classification. However, the SENIC index alone cannot determine the risk according to the type of operation. The NNIS risk index is a modification of the SENIC risk index. Some deficiencies in the SENIC system are corrected with the NNIS index. These two indexes can be used individually in studies on SSI or together, as in this study $(14,15)$.

The diagnosis of SSI is a routine part of clinical practice. However, it is much more important to determine the severity of the infection. Recognizing the wound infection alone may be sufficient to treat the patient, but some standard criteria are needed in order to be able to take prophylactic measures and to be objective in wound follow-up. In the surgical ward, many wounds that drain "serous fluid" with wound edge separation may not be recorded as SSIs, particularly if no cultures were taken. Therefore, more objective and realistic wound assessment methods were needed. The advantages of the ASEPSIS method are that it is objective, realistic and productive, and can determine the severity of the SSI. A valid infection comparison between hospitals can be made with the ASEPSIS method $(11,16)$.
The infection rate seen in group 1 (1.68\%) can be compared with other reports. In the report published by NNIS in 2001, median rates of wound infection for mastectomy ranged from $0.72 \%$ to $1.65 \%$, and those for herniorrhaphy ranged from $0.64 \%$ to $3.33 \%$ (3). In group 2 operations, the SSI rates (16.4\%) in this study were found to be higher than the NNIS reports. According to NNIS, the lowest infection rate in this group was seen in cholecystectomies (0.00\%-3.08\%), whereas the highest rate was observed in colon surgery (3.57\% -12.88\%). In group 4 operations, the rate of SSI was found higher than both NNIS and other reports $(37.2 \%)(3,18)$.

During the study, all SSI's occurred within 21 days. In the literature, follow-up time varies in different studies. Some authors recommend at least 30 days for a close follow-up period $(18,19)$. Others propose limited surveillance of wound status (20-22). In this study, ASEPSIS method was applied according to Wilson's original definition (7). The main reason of our limited follow-up period is the improvement on the cost-effectiveness of wound surveillance. The patient concordance to the follow-up program is also another problem, as observed in our study. A similar description of SSI status, after percutaneous endoscopic gastrostomy, was reported in a recent study from United Kingdom (20). In this report, the authors followed surgical wounds up to 28 days using the ASEPSIS method, which has been discussed in the surgical literature since the first report in 1986. In the articles published by Smyth and Emmerson (21) and another one published by Mangram (22) the follow-up period was proposed 21 days, (3-weeks). Therefore, the time points for wound control in the current study were chosen based on these papers (23). A 21-day surveillance period for SSIs seems adequate for a wide range of general surgical procedures.

In this study, the significance of age, BMI, ASA score, class and type of operation and type of anesthesia in relation to the de- 
Table 6. Bivariate analysis of the parameters according to status of infection

\begin{tabular}{|c|c|c|c|}
\hline Characteristic & $\begin{array}{l}\text { No wound infection } \\
\text { (ASEPSIS } \leq 20 \text { ) }\end{array}$ & $\begin{array}{l}\text { Wound infection } \\
\text { (ASEPSIS } \geq 21 \text { ) }\end{array}$ & $p$ \\
\hline Number & 2064 & 275 & \\
\hline Age & $46.2 \pm 16.16$ & $54.5 \pm 15.98$ & $<0.001$ \\
\hline $\begin{array}{l}\text { Gender } \\
\text { Female } \\
\text { Male }\end{array}$ & $\begin{array}{l}1090(52.8) \\
974(47.2)\end{array}$ & $\begin{array}{l}142(51.6) \\
133(48.4)\end{array}$ & 0.714 \\
\hline $\mathrm{BMI}$ & $25.6 \pm 3.57$ & $27.0 \pm 5.57$ & $<0.001$ \\
\hline $\begin{array}{r}\text { NNIS } \\
0 \\
1 \\
2 \\
3\end{array}$ & $\begin{array}{l}1286(62.3) \\
690(33.4) \\
72(3.5) \\
16(0.8)\end{array}$ & $\begin{array}{l}53(19.3) \\
111(40.4) \\
71(25.8) \\
40(14.5)\end{array}$ & $<0.001$ \\
\hline $\begin{array}{c}\text { SENIC } \\
0 \\
1 \\
2 \\
3 \\
4\end{array}$ & $\begin{array}{c}991(48.0) \\
931(45.1) \\
123(6.0) \\
19(0.9) \\
0\end{array}$ & $\begin{array}{c}16(5.8) \\
118(42.9) \\
97(35.3) \\
40(14.5) \\
4(1.5)\end{array}$ & $<0.001$ \\
\hline $\begin{array}{c}\text { ASA } \\
\text { I } \\
\text { II } \\
\text { III } \\
\text { IV }\end{array}$ & $\begin{array}{c}189(9.2) \\
1135(55.0) \\
704(34.1) \\
36(1.7) \\
\end{array}$ & $\begin{array}{c}8(2.9) \\
76(27.7) \\
164(59.6) \\
27(9.8) \\
\end{array}$ & $<0.001$ \\
\hline $\begin{array}{l}\text { Class of operation } \\
\qquad \begin{array}{l}\text { Group } 1 \\
\text { Group } 2 \\
\text { Group } 3 \\
\text { Group } 4\end{array}\end{array}$ & $\begin{array}{c}989(47.9) \\
958(46.4) \\
1(0.1) \\
116(5.6)\end{array}$ & $\begin{array}{c}17(6.2) \\
189(68.7) \\
- \\
69(25.1) \\
\end{array}$ & $<0.001$ \\
\hline $\begin{array}{c}\text { Type of operation } \\
\text { Elective } \\
\text { Emergency }\end{array}$ & $\begin{array}{c}1869(90.6) \\
195(9.4)\end{array}$ & $\begin{array}{l}198(72) \\
77(28)\end{array}$ & $<0.001$ \\
\hline $\begin{array}{l}\text { Type of anesthesia } \\
\text { General } \\
\text { Spinal } \\
\text { Epidural } \\
\text { Spinal and epidural }\end{array}$ & $\begin{array}{c}1719(83.3) \\
245(11.9) \\
83(4.0) \\
17(0.8)\end{array}$ & $\begin{array}{c}262(95.4) \\
11(4.0) \\
1(0.3) \\
1(0.3)\end{array}$ & $<0.001$ \\
\hline
\end{tabular}

velopment of SSI was clearly shown in bivariate analysis. BMI, ASA score and class and type of operation were found as independent risk factors for according to logistic regression analysis. These results are concordant with other studies. The relationship between emergency operations and SSI has been also shown in a study from Denmark (24). In their study, less SSI (6\%) was found in elective GIS operations compared to emergency GIS operations (16\%). The relationship between obesity and SSI is well doc- umented $(25,26)$. Age and ASA score are considered as independent variables in the development of SSI (18). The role of general anesthesia on SSI pathogenesis is not fully understood yet. Untill recent studies, a negative effect of general anesthesia on wound healing was not shown, however, recent studies have shown that general anesthesia may be a risk factor for the development of SSI $(27,28)$. In this study, the low number of patients undergoing regional anesthesia led to bias among type of anesthesia. 
Table 7. Multivariate logistic regression analyses of output parameters (SSI)

\begin{tabular}{|c|c|c|c|}
\hline Independent predictors & OR & $\mathrm{Cl}$ & $\mathbf{p}$ \\
\hline AGE & 0.99 & $0.98-1.00$ & 0.426 \\
\hline BMI & 1.06 & 1.03-1.10 & $<0.001$ \\
\hline ASA Score (I-IV) & 2.59 & $1.89-3.55$ & $<0.001$ \\
\hline Type of operation (elective or emergency) & 3.06 & $2.13-4.42$ & $<0.001$ \\
\hline Operation class* & & & $<0.001$ \\
\hline Group 2 & 7.8 & $4.46-13.88$ & $<0.001$ \\
\hline Group 4 & 28.5 & $15-18-53.72$ & $<0.001$ \\
\hline
\end{tabular}

With the SENIC project that started in 1974, it has been shown that nasocomial infections decreased by one third by following up nosocomial infections and informing the hospital staff of their results (6). As in the study of Haley et al., in our study compering the SSI rates of first year with the increased rates of second and third year was because of the correct recognition of SSI; And the decrease in the fourth year has been thought as a result of the clinical physicians' more careful, in terms of SSI in the peroperative period. During this study we also recognised that especially at education hospitals postoperative wound assement must be the one of the main subjects to be tought to surgical residents, as SSIs can be preventible more than 50\% just with assesment. In this sense, we believe that it will be beneficial for surgical units to share their own SSI results with clinical or hospital staff, and to reduce SSI rates by both continuing awareness and monitoring risk factors by reminding them.

In our study, the SENIC risk index was found to have a better correlation with the ASEPSIS wound tracking scale than the NNIS risk index. However, rs values of both indexes are below 0.75. This shows a weak relationship between parameters. New studies should be conducted to increase the sensitivity and specificity of these indexes. The number of wound infections calculated according to the ASEPSIS method includes delay in wound healing, minor, moderate and severe wound infections. Depending on these differences, the calculated number of SSIs may be higher than other SSI classification systems.

In conclusion, higher than expected rate of surgical wound infection for group 2 and 4 classes of operations were found in this study. This difference is due to intrinsic and extrinsic conditions of the study era. A weak correlation was found between the preoperative risk index scales for SSI (NNIS and SENIC) and the ASEPSIS method. In fact, the SENIC index has been modified with NNIS, but the fact that the ASEPSIS method has a weaker correlation with NNIS has shown the necessity of developing NNIS. The application of ASEPSIS method to postoperative pa- tients is found simple and repeatable. Surveillance tasks with feedback to clinical surgery staff are considered to be important in the care of patients.

Ethics Committee Approval: The approval for this study was obtained from Ankara City Hospital No. 1 Clinical Research Ethics Committee (Decision No: E1-21-1643, Date: 17.03.2021).

Peer-review: Externally peer-reviewed.

Author Contributions: Concept - M.A., S.T.; Design - S.T., M.A., E.P.; Supervision - S.T., F.M.A., S.H.; Materials - M.A., T.A.; Data Collection and/or Processing - M.A., E.P.; Analysis and/or Interpratation - E.K. Literature Review - M.A.; Writing Manuscript - M.A., S.T.; Critical Reviews - S.T., S.H.

Conflict of Interest: The authors declare that they have no conflict of interest.

Financial Disclosure: The authors declared that this study has received no financial support.

\section{REFERENCES}

1. Ban KA, Minei JP, Laronga C, Harbrecht BG, Jensen EH, Fry DE, et al. American College of Surgeons and Surgical Infection Society: Surgical Site Infection Guidelines, 2016 Update. J Am Coll Surg 2017; 224(1): 59-74. [CrossRef]

2. National Nosocomial Infections Surveillance (NNIS) system report. Data summary from January 199-June 2001, issued August 2001. Am J Infect Control 2001; 29(6): 404. [CrossRef]

3. Haley RW, Culver DH, White JW, Emori TG, Munn VP, Hooton TM. The efficacy of infection surveillance and control programs in preventing nosocomial infections in U.S. hospitals. Am J Epidemiol 1985; 121(2): 182. [CrossRef]

4. Emori TG, Culver DH, Horan TC, Jarvis WR, White JW, Olson DR, et al. National Nosocomial Infections Surveillance (NNIS) system: Description of surveillance methods. Am J Infect Control 1991; 19(1): 19. [CrossRef]

5. Bruce J, Russell EM, Mollison J, Krukowski ZH. The quality of measurement of surgical wound infection as the basis for monitoring: A systematic review. J Hosp Infect 2001; 49(2): 99-108. [CrossRef]

6. Wilson APR, Weavill C, Burridge J, Kelsey MC. The use of the wound scoring method "ASEPSIS" in postoperative wound surveillance. J Hosp Infect 1990; 16(4):297. [CrossRef] 
7. Smyth ETM, Emmerson AM. Surgical site infection surveillance. J Hosp Infect 2000; 45(3): 173-84. [CrossRef]

8. Klotz HP, Candidas D, Platz A, Kelsey MC. Preoperative risk assessment in elective general surgery. Br J Surg 1996; 83(12): 1788. [CrossRef]

9. Horan TC, Gaynes RP, Martone WJ, Jarvis, WR, Emori TG. CDC definitions of nosocomial surgical site infections, 1992: a modification of CDC definitions of surgical wound infections. Infect Control Hosp Epidemiol 1992; 13(10): 606. [CrossRef]

10. Bryne DJ, Napier A, Cuschieri A. Validation of the ASEPSIS method of wound scoring in patients undergoing general surgical operations. J R Coll Surg Edinb 1988; 33(3): 154-5. [CrossRef]

11. Nosocomial infection rates for interhospital comparison: Limitations and possible solutions. Infect Control Hosp Epidemiol 1991; 12(10): 609. [CrossRef]

12. Gaynes RP, Culver DH, Emori TG, Horan TC, Banerjee SN, Edwards JR, et al. The National Nosocomial Infections Surveillance (NNIS) system: plans for the 1990s and beyond. Am J Med 1991; 91(Supp/3B): 116S. [CrossRef]

13. Avato JL, Lai KK. Impact of postdischarge surveillance on surgical-site infection rates for coronary artery bypass procedures. Infect Control Hosp Epidemiol 2002; 23(7): 364. [CrossRef]

14. Christou NV, Jarand J, Sylvestre JL, McLean APH. Analysis of the incidence and risk factors for wound infections in open bariatric surgery. Obes Surg 2004; 14(1): 16. [CrossRef]

15. Wilson APR, Gibbons C, Hodgson B, Liu M, Plummer D, Krukowski $\mathrm{ZH}$, et al. Surgical wound infection as a performance indicator: Agreement of common definitions of wound infection in 4773 patients. BMJ 2004; 329(7468): 720. [CrossRef]

16. de Oliveira AC, Ciosak SI, Ferraz EM, Grinbaum RS. Surgical site infection in patients submitted to digestive surgery: risk prediction and the NNIS risk index. Am J Infect Control 2006; 34(4): 201. [CrossRef]

17. Reid R, Simcock JW, Chisholm L, Dobbs B, Frizelle FA. Postdischarge clean wound infections: Incidence underestimated and risk factors overemphasized. ANZJ Surg 2002; 72(5): 339. [CrossRef]
18. Weiss CA, Statz CL, Dahms RA, Remucal MJ, Dunn DL, Beilman GJ. Six years of surgical wound infection surveillance at a tertiary care center. Arch Surg 1999; 134(10): 1041. [CrossRef]

19. Panigrahi H, Shreeve DR, Tan WC, Prudham R, Kaufman R. Role of antibiotic prophylaxis for wound infection in percutaneous endoscopic gastrostomy (PEG): result of a prospective double-blind randomized trial. J Hosp Infect 2002; 50(4): 312. [CrossRef]

20. Smyth ET, Emmerson AM. Surgical site infection surveillance. J Hosp Infect 2000; 45(3): 173. [CrossRef]

21. Mangram AJ, Horan TC, Pearson ML, Silver LC, Jarvis WR. Guideline for prevention of surgical site infection, 1999. Hospital infection control practices advisory committee. Infect Control Hosp Epidemiol 1999; 20(4): 250. [CrossRef]

22. Topaloglu S, Akın M, Avşar MF, Özel H, Polat E, Akın T, et al. Correlation of risk and postoperative assesment methods in wound surveillance. J Surg Res 2008; 146(2): 211-7. [CrossRef]

23. Sorensen $L T$, Hemmingsen $U$, Kallehave F, Wille-Jørgensen P, Johan Kjaergaard, Nørgaard Møller L, et al. Risk factors for tissue and wound complications in gastrointestinal surgery. Ann Surg 2005; 241(4): 654 [CrossRef]

24. Israelsson LA, Jonsson T. Overweight and healing of midline incisions: the importance of suture technique. Eur J Surg 1997; 163(3):175. [CrossRef]

25. Shapiro M, Munoz A, Tager IB, Schoenbaum SC, Polk BF. Risk factors for infection at the operative site after abdominal or vaginal hysterectomy. N Engl J Med 1982; 307(27): 1661. [CrossRef]

26. Hirsemann S, Sohr D, Gastmeier K, Gastmeier P. Risk factors for surgical site infections in a free-standing outpatient setting. Am J Infect Control 2005; 33(1): 6. [CrossRef]

27. Treschan TA, Taguchi A, Ali SZ, Sharma N, Kabon B, Sessler DI, et al. The effects of epidural and general anesthesia on tissue oxygenation. Anesth Analg 2003; 96(6): 1553. [CrossRef] 


\section{ORIJINAL ÇALIŞMA-ÖZET}

Turk J Surg 2021; 37 (2): 133-141

\section{Farkındalık ve yara yeri takibi cerrahi alan enfeksiyonlarını azaltıyor}

Merve Akın ${ }^{1}$, Serdar Topaloğlu² ${ }^{2}$, Hakan Özel ${ }^{1}$, Fatih M. Avşar ${ }^{1}$, Tezcan Akın ${ }^{1}$, Erdal Polat ${ }^{3}$, Erdem Karabulut ${ }^{4}$, Süleyman Hengirmen $^{5}$

${ }^{1}$ Ankara Şehir Hastanesi, Genel Cerrahi Kliniği, Ankara, Türkiye

2 Karadeniz Teknik Üniversitesi Tıp Fakültesi, Genel Cerrahi Anabilim Dalı, Trabzon, Türkiye

${ }^{3}$ Kartal Koşuyolu Yüksek Ihtisas Eğitim ve Araştırma Hastanesi, Gastroenterolojik Cerrahi, İstanbul, Türkiye

${ }^{4}$ Hacettepe Üniversitesi Tıp Fakültesi, Biyoistatistik Anabilim Dalı, Ankara, Türkiye

${ }^{5}$ Ankara Numune Eğitim ve Araştırma Hastanesi, Genel Cerrahi Kliniği, Ankara, Türkiye

\section{ÖZET}

Giriş ve Amaç: Yara yeri enfeksiyonlar'ı için birçok takip metodu tanımlanmıştır. Bu çalışmanın amacı cerrahi alan enfeksiyonların'da (CAE) risk belirleme metotları olan SENIC ve NNIS ile postoperatif yara takip skalası olan ASEPSIS'in karşılıklı olarak değerlendirmesi ve yara takibinin yara yeri enfeksiyonun azalmasına katkısının değerlendirilmesi

Gereç ve Yöntem: Kliniğimizde dört yıl boyunca ameliyat olan hastalar prospektif olarak izlendi. SENIC, NNIS, ve ASEPSIS metotlarına göre kayıtlar tutuldu.

Bulgular: Çalışma süresince 275 CAE oluştu. CAE operasyondan sonraki 21 günlük süre içinde belirlendi. SENIC ve ASEPSIS arasındaki ilişki (rs= $0,41, p<0,001$ ); NNIS ile ASEPSIS arasındaki ilişkiden ( $r s=0,37 ; p<0,0001$ ) daha uyumlu bulundu. Operasyon tipi (acil ve elektif), vücut-kitle indeksi (BMI), operasyon sınıfı ve Amerikan Anestezyoloji Derneği (ASA) skoru CAE için bağımsız faktörler olarak belirlendi. Dördüncü yıl CAE oranı diğer yıllara göre anlamlı olarak az bulundu $(p<0,001)$.

Sonuç: Bu çalışma preoperatif risk belirleme skalaları ile ASEPSIS metodu arasında zayıf ama anlamlı bir ilişki olduğunu belirtmektedir. Ayrıca yara takibinin yapılması ve yara yeri enfeksiyon oranlarının bilinmesi yıllar içinde CAE oranlarını azaltmıştır.

Anahtar Kelimeler: Asepsis, senic, cae, nnis

Doi: $10.47717 /$ turkjsurg.2021.5059 